\title{
Early Navel Orange Fruit Yield, Quality, and Maturity in Response to Late-season Water Stress
}

\author{
Craig E. Kallsen ${ }^{1}$ and Blake Sanden \\ University of California Cooperative Extension, Kern County, 1031 S. Mt. \\ Vernon Avenue, Bakersfield, CA 93307
}

\author{
Mary Lu Arpaia \\ Department of Botany and Plant Sciences, University of California, Riverside, \\ CA 92521
}

Additional index words. BrimA, Citrus sinensis (L.) Osbeck, leaf water potential

\begin{abstract}
The objective of this study was to measure effects of late-season water stress on fruit yield, size, quality, and color of an early-maturing navel orange cultivar, Citrus sinensis (L.) Osbeck 'Beck-Earli'. Three irrigation regimes were initiated in August in the southern San Joaquin Valley of California in 2006, 2007, and 2008. Increasing levels of water stress resulted in decreasing midday shaded leaf water potential (SLWP) ranging from -1.4 MPa in early September to a minimum of -2.5 MPa at harvest. Generally, over the course of the 3 years, late-season water stress decreased fruit grade and increased soluble solids concentration (SSC), titratable acidity (TA), the BrimA index, and orange color. Fruit juiciness and SSC:TA ratios were unaffected by late-season water stress. The intensity of the water stress in 2007 decreased fruit yield by number and weight and decreased the percentage of large fruit. When trees exposed to 2 years of late-season water stress were fully irrigated the next year, fruit yield and quality were similar to trees that had not experienced late-season water stress for the 3 years of the study.
\end{abstract}

In the southern San Joaquin Valley, earlymaturing navel orange [Citrus sinensis (L.) Osbeck] cultivars such as Beck-Earli, Newhall, and Fukumoto produce the first harvestable navel orange fruit of the season in California. Before harvest may occur, fruit must meet minimum regulatory standards for juice, sugar, and acid as well as peel color. The first harvest typically begins in late October or early November. Delaying harvest past November will result in larger, sweeter, and full-colored fruit, but at the cost of missing the price premium that the market pays for earliness (U.S. Dept. Agr., 2009a, 2010). Irrigation appears to influence fruit size, quality, yield, and harvest earliness, but little scientific information is available on how it affects fruit size, quality, number of fruit, and harvest date of earlymaturing navel oranges in the San Joaquin Valley. The concept of using deficit irrigation to influence fruit yield and quality of oranges is not new (Hilgeman and Sharp, 1970; Miller and Turnbull, 1948). Other citrus researchers have experimented with periodic water deficits during the growing season. Water stress can affect fruit yield and quality. Summer, fall,

\footnotetext{
Received for publication 23 Feb. 2011. Accepted for publication 6 June 2011.

We acknowledge the California Citrus Research Board for their financial support of this project, our cooperating orange grower Fry and Sons Citrus Orchards, and Ken Shackel and Brent Holtz for their valuable suggestions in preparing the manuscript.

${ }^{1}$ To whom reprint requests should be addressed; e-mail cekallsen@ucdavis.edu.
}

and season-long water deficits have increased the concentration of juice SSC, especially sugars, through short-term fruit dehydration or longer-term osmotic adjustment, although the ratio of SSC to percent TA changed little (Barry et al., 2004; Hilgeman and Sharp, 1970; Hutton et al., 2007; Perez-Perez et al., 2009; Treeby et al., 2007; Yakushiji et al., 1996). Summer, fall, and season-long water deficits have been shown to decrease fruit size in oranges and mandarins (Goldhamer, 2007; Goldhamer and Salinas, 2000; Hutton et al., 2007; Perez-Perez et al., 2009; Romero et al., 2006; Treeby et al., 2007). The effect of lateseason water stress on yield has been mixed with some researchers reporting no change (Hutton et al., 2007; Perez-Perez et al., 2009) and others reduced yields (Goldhamer, 2007; Goldhamer and Salinas, 2000). Rootstocks can influence the response of the citrus scion to water deficit (Barry et al., 2004; Romero et al., 2006; Treeby et al., 2007).

Although deficit irrigation has been shown to decrease yield by weight and fruit numbers, it has been used to increase grower financial returns by increasing fruit grade and value through a reduction in rind creasing in 'Frost Nucellar' navel orange (Goldhamer and Salinas, 2000) and by reducing fruit granulation and moderating fruit size in 'Lane Late' navel oranges (Goldhamer, 2007).

The objective of our study was to measure the effects of differential levels of late-season water stress as quantified by reductions in leaf water potential from well-watered 'Beck-Earli' navel orange trees on yield and fruit quality during the stress period.
Experimental trees and site description. The experiment was conducted from Spring 2006 through Oct. 2008 in a commercial orchard planted in 1994 and located adjacent to the foothills in the southwestern corner of the San Joaquin Valley near the town of Mettler, CA (lat. $35.0365^{\circ} \mathrm{N}$; long. $119.0417^{\circ} \mathrm{W}$ ). The average annual precipitation of the experimental location is $\approx 200 \mathrm{~mm}$ and was appropriate for a late-season water stress experiment in that rainfall from August through October was less than $25 \mathrm{~mm}$ over the 3 years of the experiment (Table 1). Average solar radiation at this site in August is $\approx 300 \mathrm{~W} \cdot \mathrm{m}^{-2}$.

The orchard trees, 'Beck-Earli' navel orange grafted on Carrizo citrange [Citrus sinensis (L.) Osbeck $\times$ Poncirus trifoliata (L.) Raf.] rootstock, were uniform and healthy in appearance. Testing by the California Central Tristeza Eradication Agency in May 2006 found citrus tristeza virus infection rates less than $0.18 \%$ in this orchard. The east-westrunning tree rows were $6.7 \mathrm{~m}$ apart with $3.4 \mathrm{~m}$ between trees within the row. During the course of the experiment, tree height was maintained by mechanical topping and varied from 3.0 to $3.7 \mathrm{~m}$. The soil was a neutral, deep, welldrained Cerini coarse sandy clay loam with good infiltration and high water-holding capacity (U.S. Dept. Agr., 2009b).

Experimental design. The experimental site was established within an area 45-tree rows wide by 30 trees deep within a 16-ha orchard of 'Beck-Earli' navel orange trees. The experiment was designed as a randomized, complete block providing five replications of each of three irrigation treatments. An irrigation treatment was applied to an experimental unit, which consisted of a plot (aka replicate) three rows wide $\times 10$ trees long. Data were collected from the eight trees in the center of the center row of each plot with the two neighboring rows functioning as borders as did the first and tenth trees of the center row. Each replicate was further divided for fruit sampling purposes as a split plot based on the side of the tree (north versus south side).

Irrigation treatments. A treatment was identified by the record of the relative amount of water applied to plots of trees over the 3year period of this study (Table 1). Three different levels of irrigation designated as $\mathrm{T} 1$, $\mathrm{T} 2$, and $\mathrm{T} 3$, respectively, were applied to achieve varying levels of late-season water stress from late August through harvest in midto late October. In all 3 years, neutron probe measurements indicated that trees differentially depleted water stored in the soil as the season progressed depending on irrigation treatment (data not shown). T3 was designed to be a fully irrigated control until $\approx 2$ weeks before harvest when most growers begin reducing irrigation. Drier soils reduce fruit turgidity and associated oleocellosis, which may occur during harvest and transportation of the fruit to the packing house (Naqvi, 2004; Shorner and Erner, 1989). In 2006 and 2007, T3 received the greatest amount of applied water during the late-season stress period from 
August through fruit harvest in Oct., T2 an intermediate amount, and T1 the least (Table 1). T2 was an intermediate deficit irrigation treatment in 2006, 2007, and 2008. T1 received the least applied water in 2006 and 2007 but, as a result of grower concerns over the future health of the trees, was converted to a drought recovery treatment in 2008 and received the same irrigation as T3.

The degree of water stress was quantified by SLWP measurements. Irrigation treatments were initiated in early August in these deep soils with the objective of achieving differential levels of SLWP by late August.

Generally, the cooperating grower within whose orchard the experiment was located scheduled irrigations that normally occurred weekly during the summer. Within our experiment we were responsible for applying differential irrigation treatments. Differential irrigation was accomplished with the use of irrigation emitters with different flow rates and by opening or closing valves in the hoses between irrigation treatments. Water flow meters (Precision Meter, Capetown, South Africa) were installed in the irrigation hoses between treatment replicates. Neutron probe access tubes were installed to a soil depth of $1.6 \mathrm{~m}$ in each replicate. Thus, water application rates, soil-water status, and plant SLWP could be measured at weekly intervals and in combination with the anticipated additional irrigation water scheduled to be applied by the cooperating grower, sufficient information was available to adjust the system as necessary to maintain or increase SLWP by treatment.

At any given time, a tree was irrigated by a single "green," "orange," "black" Fanjet $\AA$, or M200 series drip manifold (Bowsmith Inc., Exeter, CA) emitting 70, 36, 25, and $12 \mathrm{~L} \cdot \mathrm{h}^{-1}$ of water, respectively, depending on treatment and time of the year. After harvest, depleted soil-water in the profile was restored by changing to emitters with higher flow rates in the deficit-irrigated treatments (Table 2). The green Fanjet was only used during winter to restore water in the top meter of the soil profile in T1. The drip manifold was used exclusively during the stress period in $\mathrm{T} 1$.

Based on estimated normal evapotranspiration (ET) of citrus in the San Joaquin Valley (California Dept. of Water Resources, 1993) and soil-water depletion as measured by the neutron probe, excess irrigation above estimated ET was deliberately applied to T3 beginning in August of 2007; to treatments T1, $\mathrm{T} 2$, and $\mathrm{T} 3$ after harvest in 2007 and before imposition of stress in Aug. 2008; and during the late-season stress period in T1 and T3 in 2008 to ensure the trees were fully irrigated and that soil water was recharged in the root zone (Table 1).

All nitrogen in this experiment was applied in the spring through the irrigation system using black or orange Fanjets, depending on year, at an annual rate of $125 \mathrm{~kg} \cdot \mathrm{ha}^{-1} \mathrm{re}-$ gardless of irrigation treatment.

Measurement of tree water stress. Water stress was quantified by plant water status (Goldhamer et al., 2001; Shackel, 2011; Shackel et al., 1997). Midday SLWP was

Table 1. Estimated crop evapotranspiration, precipitation, and irrigation applied by treatment and crop period to 'Beck-Earli' navel orange in the southern San Joaquin Valley, 2006 to 2008.

\begin{tabular}{|c|c|c|c|c|c|c|}
\hline \multirow[b]{2}{*}{ Treatment } & \multicolumn{2}{|c|}{2006} & \multicolumn{2}{|c|}{ 2006-2007 } & \multicolumn{2}{|c|}{ 2007-2008 } \\
\hline & Period $\mathrm{A}^{\mathrm{z}}$ & Period B & Period A & $\overline{\text { Period B }}$ & Period A & $\overline{\text { Period B }}$ \\
\hline & \multicolumn{6}{|c|}{ Irrigation $^{y}(\mathrm{~mm})$} \\
\hline $\mathrm{T} 1^{\mathrm{x}}$ & $302 \mathrm{a}^{\mathrm{w}}$ & $95 \mathrm{c}$ & $546 \mathrm{~b}$ & $114 \mathrm{c}$ & $828 \mathrm{a}$ & $334 \mathrm{~b}$ \\
\hline $\mathrm{T} 2$ & $314 \mathrm{a}$ & $175 \mathrm{~b}$ & $561 \mathrm{~b}$ & $228 \mathrm{~b}$ & $810 \mathrm{a}$ & $156 \mathrm{a}$ \\
\hline $\mathrm{T} 3$ & 297 a & $235 \mathrm{a}$ & $674 \mathrm{a}$ & $378 \mathrm{a}$ & 809 a & $329 \mathrm{~b}$ \\
\hline \multirow{3}{*}{ All } & \multicolumn{6}{|c|}{ Precipitation $^{v}$ (mm) } \\
\hline & 0 & 7 & 184 & 0 & 108 & 1 \\
\hline & \multicolumn{6}{|c|}{$\mathrm{ET}_{\mathrm{c}}^{\mathrm{v}}(\mathrm{mm})$} \\
\hline All & 319 & 273 & 760 & 261 & 858 & 301 \\
\hline
\end{tabular}

"Periods defined: "A" refers to non-stress time periods. "A" in 2006 was from 23 May to 6 Aug., in 2007 from post-harvest 2006 to 6 Aug. 2007, and in 2008 from postharvest 2007 to 6 Aug. 2008. "B" refers to the period of irrigation stress which occurred from 7 Aug. to harvest all years. Fruit harvested, 30 Oct. 2006, 15 Oct. 2007, and 29 Oct. 2008.

${ }^{y}$ Each value is the average of five water meters, one for each replicated plot.

${ }^{\mathrm{x}} \mathrm{T} 1, \mathrm{~T} 2$, and $\mathrm{T} 3$ refer to the three irrigation treatments conducted over the 3 years of the experiment.

wValues that are followed by different letters in the same column in a given period across treatments are significantly different by Fisher's protected least significant difference test at $P \leq 0.05$.

"Estimated crop evapotranspiration and measured precipitation from a CIMIS weather station located $24 \mathrm{~km}$ northeast of the study site.

Table 2. Irrigation emitters used to produce a range of late-season water stress in navel orange and to refill the soil profile before the subsequent growing season, Southern San Joaquin Valley, 2006 to 2008.

\begin{tabular}{cllc}
\hline Yr and & \multicolumn{2}{c}{ Period } \\
\cline { 2 - 4 } treatment & \multicolumn{1}{c}{ Pre-stress } & Stress 7 Aug. to harvest & Post-stress \\
\hline 2006 & 23 May to 6 Aug. & 7 Aug. to 30 Oct. & 31 Oct. to 15 May \\
T1 & Black fan $^{y}$ & Drip manifold & Orange fan \\
T2 & Black fan & Black fan & Black fan \\
T3 & Black fan & Orange fan & Black fan
\end{tabular}

$\begin{array}{rllll}2007 & \text { 16 May to 6 Aug. } & \text { 7 Aug. to 15 Oct. } & \text { 16 Oct. to 20 Nov. } & \text { 21 Nov. to 10 Feb. } \\ \text { T1 } & \text { Orange fan } & \text { Drip manifold } & \text { Orange fan } & \text { Green fan } \\ \text { T2 } & \text { Orange fan } & \text { Black fan } & \text { Black fan } & \text { Black fan } \\ \text { T3 } & \text { Orange fan } & \text { Orange fan } & \text { Black fan } & \text { Black fan }\end{array}$

$2008 \quad 10$ Feb. to 6 Aug. 7 Aug. to 29 Oct. Experiment ended 30 Oct

T1 Orange fan Orange fan

T2 Orange fan Black fan

T3 Orange fan Orange fan

${ }^{\mathrm{z}} \mathrm{T} 1, \mathrm{~T} 2$, and $\mathrm{T} 3$ refer to the three irrigation treatments conducted over the 3 years of the experiment. "A tree was irrigated by a single "green," "orange," "black" Fanjet ${ }^{\circledR}$ or M200 series drip manifold (Bowsmith Inc., Exeter, CA) emitting 70, 36, 25, and $12 \mathrm{~L} \cdot \mathrm{h}^{-1}$ of water, respectively.

measured using a pressure chamber (Model 1000; Pressure Measurement Systems Instrument Co., Albany, OR) in a technique used by Goldhamer and Salinas (2000). Measurements were made weekly, from late July through harvest in 2006, 2007, and 2008, on two mature, fully expanded, interior-shaded leaves from the north side of the canopy from each of the three trees in each plot reserved for harvest evaluation. No difference in SLWP values were obtained between bagged and unbagged leaves sampled from similar locations within a single tree canopy in early testing (data not shown) probably as a result of the shaded location and thick, waxy cuticle of citrus leaves (Oosterhuis et al., 1988; Schreider and Riedereer, 1996). Therefore, subsequent SLWP measurements were made on unbagged leaves, which reduced handling and possible damage to the leaf surface in the bagging process before sampling. The measurements were generally made on clear, sunny days between 1200 and $1500 \mathrm{HR}, 1$ or $2 \mathrm{~d}$ before the next irrigation indicating that the trees were near maximum levels of water stress for that period. Reference evapotranspiration (ETo) was obtained from the nearest California Irrigation Management Information System (CIMIS) weather station located $24 \mathrm{~km}$ northeast of and in the same CIMIS Reference Evapotranspiration Zone as our study site. The CIMIS system uses a modified Penman equation (Pruitt and Doorenbos, 1977), which uses a wind function developed by the University of California, to calculate ETo from measured weather variables (CIMIS, 2011). Crop ET (ETc) was calculated by multiplying ETo by the appropriate crop coefficient ( 0.67 to 0.82 ) depending on month using citrus crop coefficients described by Pruitt et al. (1987).

Fruits sampling and harvest. Within each replicate, five trees in the interior of the data row were dedicated to fruit quality sampling conducted 26 Sept. and 3, 10, 17, 24, and 30 Oct. 2006; 25 Sept. and 1, 8, and 15 Oct. 2007; and 30 Sept. and 7, 14, 21, and 28 Oct. 2008. Three trees were reserved for yield and fruit quality measurements at harvest. In 2006, 
five oranges, and in 2007 and 2008, 10 similarsized oranges were collected at weekly intervals from both the north and south sides of trees in each replicate beginning in late September and continuing through harvest. Shaded fruit, without scars or sunburn, were removed from the canopy in a band from 1.5 to 2.1 above ground level. Fruit samples were transported to the laboratory at the University of California Lindcove Research and Extension Center (LREC) in Lindcove, CA, for determination of fruit quality characteristics. Fruit peel color, width and length, fruit, and juice weight were measured. Juice percent, SSC, and percent TA in citric acid equivalents were measured using the method of Ting and Rouseff (1986). SSC was measured with a temperature-compensated refractometer (Model RFM110; Bellingham and Stanley, Tunbridge, U.K.) and TA by titration (Model DL53; Mettler Toledo, Columbus, OH). The SSC:TA ratio and BrimA were calculated. BrimA was calculated by the following formula: $\mathrm{Brim} \mathrm{A}=$ $\mathrm{SSC}-\left(0.4^{*} \mathrm{TA}\right)$. Brim A has been found to be more closely related to flavor than SSC/TA (Jordan et al., 2001; Obenland et al., 2009).

Fruit peel color was determined using three methods. Within the season and near or at harvest, fruit surface color measurements were performed on the 10 to 20 individual fruit, collected as described previously, from both the north and south sides of the trees of each replication. A single measurement was made on opposite sides of each fruit the day after sampling using a colorimeter (Model CR-300 with a Model DP-301 data processor unit using the Standard Illuminant $\mathrm{C}$ light source; Minolta, Tokyo, Japan). These two measurements were averaged to obtain a single value for a fruit, and this value for each of the 10 to 20 fruit making up each sample was used to produce an overall average. Results from the colorimeter are reported using the L* C* H color scale (McGuire, 1992; Minolta Corp. Ltd., 1994; Voss, 1992).

Color, as evaluated by the same human observers on the same fruit samples measured by the colorimeter, was based on standardized color chips with values representing colors from 1 to 13,1 being greenest and 13 the most reddish orange (Obenland et al., 2009). The color chart was developed by researchers at the University of California, Riverside, and a rating of 5 corresponded to the "A" rating, which is part of the California state maturity standards (State of California, 2003). At harvest, color was also evaluated by an automated sensor (Sunkist QP3 Grader, custom-constructed) based on the light reflectance of every fruit in the plot, sorted by size and grade, as it passed through the packline.

At final harvest, the fruits from the three designated trees in each plot were completely picked and transported to LREC for determination of yield, fruit size, grade, color, and the other quality characteristics described previously. The timing of the harvest each year was made by commercial packing house representatives and tended to coincide with the first development of legal harvest maturity of the fruit. Legal maturity is based on a sample of the fruit having a minimum SSC:TA ratio of 8.0 and minimum level of orange color. Final fruit harvest occurred 30 Oct. 2006, 15 Oct. 2007, and 29 Oct. 2008.

The final sample of the year for evaluation of fruit quality characteristics in 2006 and 2007 was removed immediately before the harvested fruit passed over the automated packline. A sample from each plot consisted of 10 fruit with average diameters of $84 \mathrm{~mm}$ (count size 56 fruit per $17-\mathrm{kg}$ California commercial carton) and included fruit from the north and south sides of the tree. For the crop year 2008, the final fruit sample was picked on 28 Oct. in separate samples from the south and north sides of the trees in each plot.

Sensory evaluation. To determine if laboratory-measured differences in SSC, TA, and juiciness would be sufficient to correlate with human sensory perception, fruit were compared from trees under the lowest and highest irrigation treatments in both 2007 and 2008. For each test, 12 to 20 panelists were available. Fruit from four replicates of the two treatments were tested. Fruit was picked for testing on 15 Oct. 2007 and 21 Oct. 2008. The fruit were stored at $5{ }^{\circ} \mathrm{C}$ and $90 \%$ relative humidity until testing at the Kearney Agricultural Research and Extension Center, Parlier. On the day of sampling, samples were taken from storage and allowed to adjust to ambient room temperature $\left(\approx 20^{\circ} \mathrm{C}\right)$. Fruit were prepared and presented in a similar to that described by Obenland et al. (2009). Sensory difference testing was conducted on fruit from each treatment and replication. Panelists received randomized pairs of samples and were asked to identify whether the samples were the "same" or "different." Panelists could re- ceive any combination of the pairs: 1 versus 1 , 1 versus 3,3 versus 3 , or 3 versus 1 .

Statistical analysis. Data were analyzed on a model encompassing the following: side of the tree, treatment, block, and year. Statistical analyses were accomplished using analysis of variance (ANOVA) and General Linear Model statistical packages in Statistica software (StatSoft, Inc., Tulsa, OK.). The ANOVAs did not demonstrate consistent interaction effects among irrigation treatments, block, or side of the tree using Fisher's protected least significant difference test at $P \leq 0.05$. For this reason, difference in fruit quality and yield characteristics have been shown in the tables as attributable to simple main treatment effects of water stress.

For the sensory evaluation component of this experiment, the results of the tests were analyzed using statistical tables generated for paired-comparison tests.

\section{Results and Discussion}

Tree water status as measured by leaf water potential. In the southern San Joaquin Valley during clear, dry, and hot summer days, well-watered midday leaf water potentials are in the range of -0.7 to $-1.1 \mathrm{MPa}$ (Elfving et al., 1972; Goldhamer and Salinas, 2000; Kallsen and Sanden, unpublished data; Romero et al., 2006). Generally, in the 3 years of this study, significant differential stress levels in the trees were not reached until late August or early September because the trees in $\mathrm{T} 1$ and $\mathrm{T} 2$ depleted stored soil water. In June and July 2006 before differential irrigation treatments began, the trees in all treatments were probably under some water stress as indicated by midday leaf water potentials in the range of -1.2 to $-1.3 \mathrm{MPa}$ (Fig. 1), even though applied

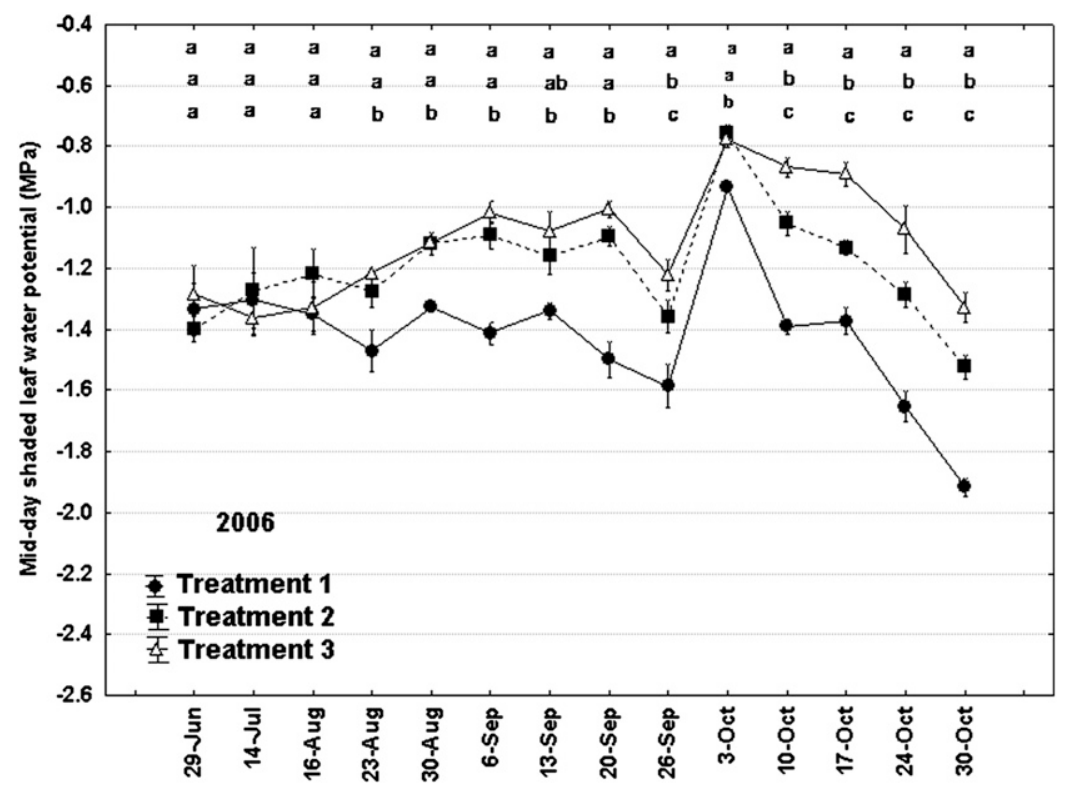

Fig. 1. Midday shaded leaf water potential of 'Beck-Earli' navel orange over time for three irrigation treatments in 2006. Differential irrigation treatments initiated in early August. At the top of the figure, different letters in a column for a given date signify significant differences by Fisher's protected least significant difference test at $P \leq 0.05$ among T3, T2, and T1 as ordered from top to bottom, respectively, in each column. Error bars denote $\pm 1 \mathrm{SE}$. 
water was close to the estimated ETc over the period (Table 1). With the onset of the differential irrigations in early Aug. 2006, water potential in the three treatments began to diverge. In 2006, differences in late-season leaf water potential between $\mathrm{T} 1$ and $\mathrm{T} 2$ were $\approx 0.2 \mathrm{MPa}$ and first appeared in late September, whereas differences between $\mathrm{T} 1$ and $\mathrm{T} 3$ began in late August and were $\approx 0.6 \mathrm{MPa}$ from early October through harvest (Fig. 1).

In 2007 , aside from a dip in early July across all treatments, water potential values in all three treatments reflect trees that were sufficiently irrigated to minimize or prevent stress before the onset of the differential irrigation treatments, which began in early August (Fig. 2). In 2007, distinct differences in water potential among the treatments were achieved, especially among the well-watered treatment, T3, and the least irrigated, T1. In 2008, T1 and T3 were irrigated similarly, and $\mathrm{T} 2$ received the mildest stress imposed on it for any year of the experiment (Fig. 3). The reduction in SLWP beginning $\approx 2$ to 3 weeks before harvest across treatments all years is the result of our cooperating grower following the practice of reducing or discontinuing late-season irrigation to reduce oleocellosis associated with greater fruit turgidity.

Water stress and changes in fruit quality. Irrigation treatment affected quality characteristics as the fruit matured. The magnitude of the differences observed may be partially the result of the Carrizo rootstock, which has been shown to be sensitive to changes in soil water content (Romero et al., 2006). As demonstrated by other researchers (Barry et al., 2004; Hilgeman and Sharp, 1970; Romero et al., 2006; Treeby et al., 2007; Yakushiji et al., 1996), juice SSC and TA were higher in stressed trees, especially in trees in T1 in 2007 that experienced the highest stress levels (Table 3). However, even the relatively mild stresses imposed in T2 in 2006, 2007, and 2008 increased SSC. Percent TA was increased by water stress but not as much as SSC (Table 3). The SSC:TA ratios were not different among irrigation treatments because both SSC and TA increased (Table 3). Differences in BrimA were found among irrigation treatments all years and this measurement was nearly as sensitive to water stress as SSC. The percentage of juice weight to fruit weight generally was unaffected by irrigation treatment (Table 3) nor was the ratio of juice volume to fruit weight (data not shown), suggesting that the increase in SSC and TA was not the result of fruit dehydration but probably fruit osmotic adjustment (Yakushiji et al., 1996).

Whether measured by eye or by colorimeter, peel color was affected by irrigation treatment (Table 4). The color components $\mathrm{L}^{*}$, chroma, and hue angle showed differences among treatments and these differences were supported by observed color comparisons made by eye. Water stress promoted the transition toward lighter fruit color, greater color intensity, and hue angle from green toward yellow and orange. Differences in color between T1 and T3 appeared early in 2007 probably as a result of

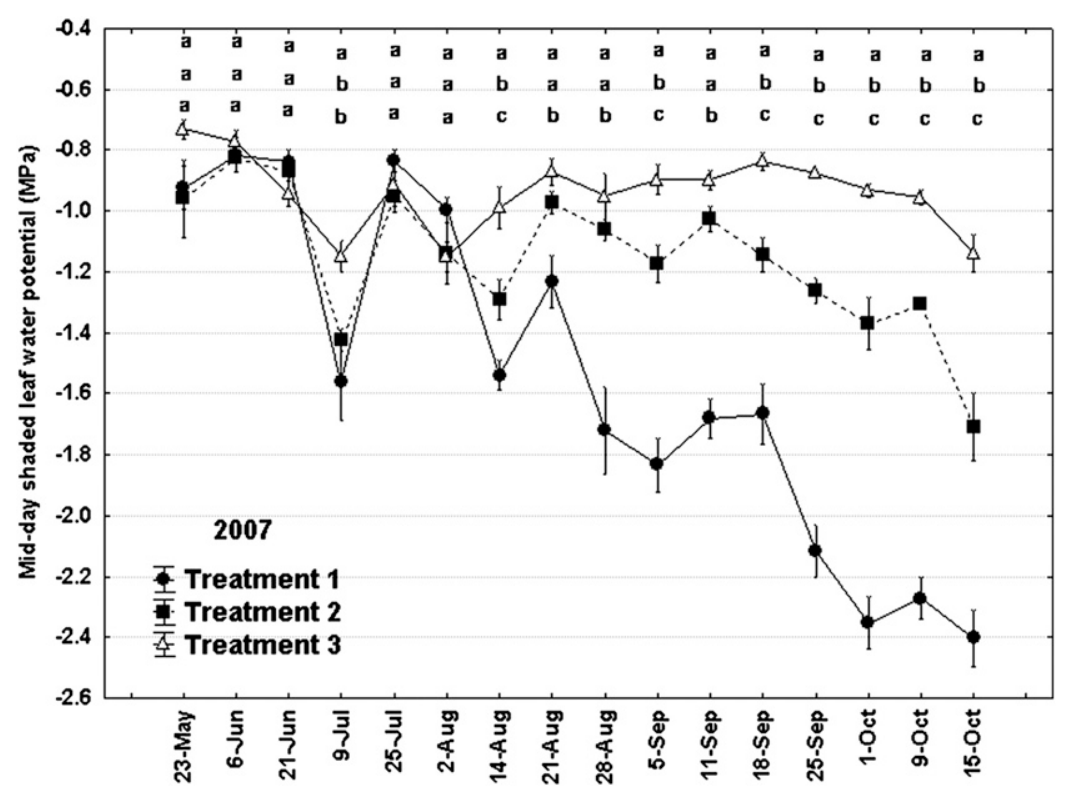

Fig. 2. Midday shaded leaf water potential of 'Beck-Earli' navel orange over time for three irrigation treatments in 2007. Differential irrigation treatments initiated in early August. At the top of the figure, different letters in a column for a given date signify significant differences by Fisher's protected least significant difference test at $P \leq 0.05$ among T3, T2, and T1 as ordered from top to bottom, respectively, in each column. Error bars denote $\pm 1 \mathrm{SE}$.

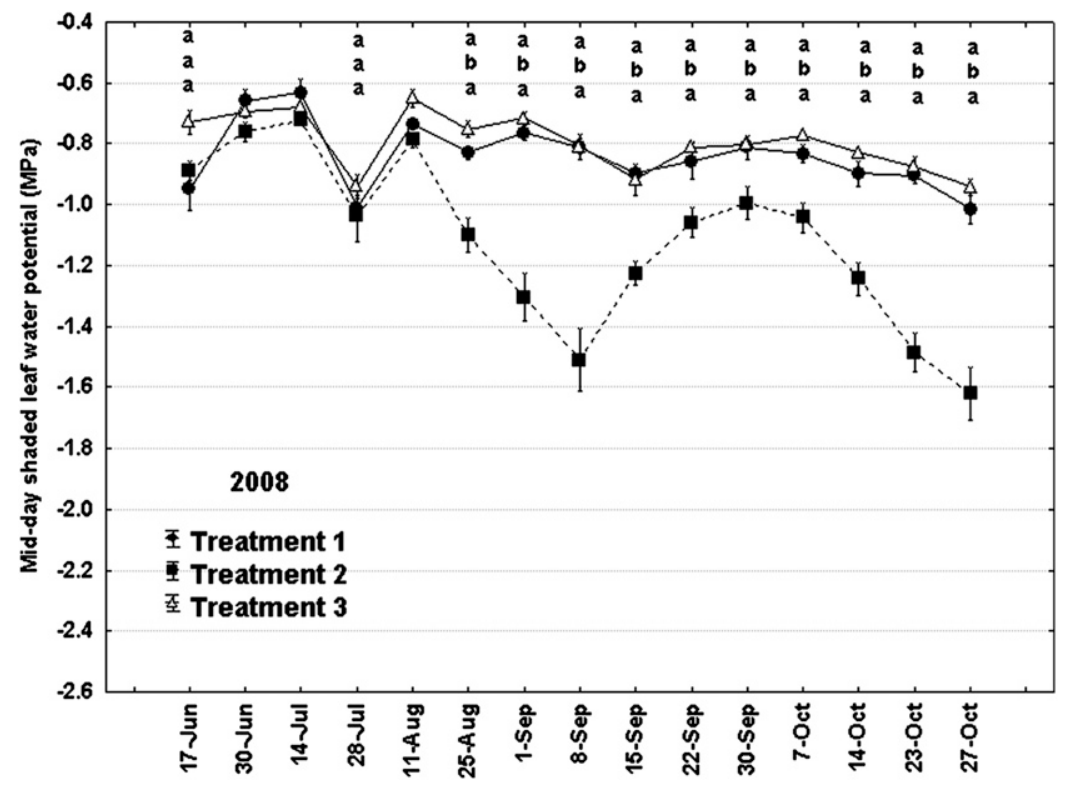

Fig. 3. Midday shaded leaf water potential over time of 'Beck-Earli' navel orange for three irrigation treatments in 2008. Differential irrigation treatments initiated in early August. At the top of the figure, different letters in a column for a given date signify significant differences by Fisher's protected least significant difference test at $P \leq 0.05$ among T3, T2, and T1 as ordered from top to bottom, respectively, in each column. Error bars denote $\pm 1 \mathrm{SE}$.

the higher levels of stress in the trees of T1 this year.

Irrespective of irrigation treatment, differences were found in some fruit quality parameters between the north and south sides of trees probably attributable to differences in light and radiant heat absorption (Syvertsen and Albrigo, 1980). For a given fruit sampling date in October of 2006, 2007, or 2008, juice percentage, SSC, TA, BrimA, and the $\mathrm{SSC}$ :TA ratio were greater on the south side of the tree compared with the north side (for simplicity, data only shown for 2007; Table 5). Some of the differences in SSC between the south and north sided of the trees may be the result of differences in juice percentage (Table 5). Fruit color development, as averaged across irrigation treatments, was the same between the south and north sides of the tree when evaluated by comparison with standard color pictures (Table 5) and by colorimeter (data not shown). 
Table 3. Effect of irrigation treatment on juiciness, soluble solids concentration (SSC), titratable acid percentage (TA), BrimA index, and the ration of soluble solids to titratable acidity of 'Beck Earli' navel fruit in the southern San Joaquin Valley, 2006, 2007, and 2008.

\begin{tabular}{|c|c|c|c|c|c|c|c|c|c|c|c|c|c|c|c|}
\hline \multirow[b]{2}{*}{ Sample date } & \multicolumn{3}{|c|}{ Juice wt to fruit wt (\%) } & \multicolumn{3}{|c|}{ Juice (SSC) (\%) } & \multicolumn{3}{|c|}{ Juice (TA) (\%) } & \multicolumn{3}{|c|}{ Juice BrimA } & \multicolumn{3}{|c|}{ SSC:TA ratio } \\
\hline & $\mathrm{T} 1^{\mathrm{y}}$ & $\mathrm{T} 2$ & T3 & T1 & $\mathrm{T} 2$ & T3 & $\mathrm{T} 1$ & $\mathrm{~T} 2$ & T3 & $\mathrm{T} 1$ & $\mathrm{~T} 2$ & T3 & $\mathrm{T} 1$ & $\mathrm{~T} 2$ & T3 \\
\hline \multicolumn{16}{|l|}{2006} \\
\hline 26 Sept. & $24 \mathrm{a}^{\mathrm{x}}$ & $26 \mathrm{a}$ & $25 \mathrm{a}$ & $9.3 \mathrm{a}$ & $8.7 \mathrm{~b}$ & $8.4 \mathrm{c}$ & $1.4 \mathrm{a}$ & $1.3 \mathrm{~b}$ & $1.2 \mathrm{~b}$ & $3.5 \mathrm{a}$ & $3.7 \mathrm{a}$ & $3.6 \mathrm{a}$ & $8.5 \mathrm{a}$ & $7.8 \mathrm{a}$ & $7.8 \mathrm{a}$ \\
\hline 3 Oct. & $26 \mathrm{a}$ & $27 \mathrm{a}$ & $25 \mathrm{a}$ & $9.5 \mathrm{a}$ & $8.9 \mathrm{~b}$ & $8.5 \mathrm{c}$ & $1.2 \mathrm{a}$ & $1.1 \mathrm{a}$ & $1.1 \mathrm{a}$ & $4.8 \mathrm{a}$ & $4.5 \mathrm{a}$ & $4.3 \mathrm{a}$ & $8.5 \mathrm{a}$ & $8.3 \mathrm{a}$ & $8.2 \mathrm{a}$ \\
\hline 10 Oct. & $28 \mathrm{a}$ & $28 \mathrm{a}$ & $28 \mathrm{a}$ & $9.5 \mathrm{a}$ & $9.0 \mathrm{~b}$ & $8.7 \mathrm{c}$ & $1.2 \mathrm{a}$ & $1.1 \mathrm{a}$ & $1.1 \mathrm{a}$ & $4.7 \mathrm{a}$ & $4.6 \mathrm{a}$ & $4.1 \mathrm{~b}$ & $8.0 \mathrm{a}$ & $8.3 \mathrm{a}$ & $7.7 \mathrm{a}$ \\
\hline 17 Oct. & $27 \mathrm{a}$ & $29 \mathrm{a}$ & $29 a$ & $10.1 \mathrm{a}$ & $9.5 \mathrm{~b}$ & $9.0 \mathrm{c}$ & $1.1 \mathrm{a}$ & $1.1 \mathrm{a}$ & $1.0 \mathrm{a}$ & $5.6 \mathrm{a}$ & $5.2 \mathrm{~b}$ & $4.9 \mathrm{~b}$ & $9.2 \mathrm{a}$ & $8.9 \mathrm{a}$ & $8.9 \mathrm{a}$ \\
\hline 24 Oct. & $28 \mathrm{a}$ & $32 \mathrm{a}$ & $28 \mathrm{a}$ & $10.1 \mathrm{a}$ & $9.5 \mathrm{~b}$ & $9.2 \mathrm{c}$ & $1.1 \mathrm{a}$ & $1.0 \mathrm{a}$ & $1.0 \mathrm{a}$ & $5.8 \mathrm{a}$ & $5.6 \mathrm{a}$ & $5.1 \mathrm{~b}$ & $9.5 \mathrm{a}$ & $9.9 \mathrm{a}$ & $9.1 \mathrm{a}$ \\
\hline 30 Oct. & $25 \mathrm{a}$ & $27 \mathrm{a}$ & $27 \mathrm{a}$ & $10.8 \mathrm{a}$ & $9.8 \mathrm{~b}$ & $9.3 \mathrm{c}$ & $1.1 \mathrm{a}$ & $1.0 \mathrm{a}$ & $1.0 \mathrm{a}$ & $6.6 \mathrm{a}$ & $5.8 \mathrm{a}$ & $5.4 \mathrm{~b}$ & $10.4 \mathrm{a}$ & $10.1 \mathrm{a}$ & $9.4 \mathrm{a}$ \\
\hline \multicolumn{16}{|l|}{2007} \\
\hline 25 Sept. & $27 \mathrm{a}$ & $27 \mathrm{a}$ & $27 \mathrm{a}$ & $10.3 \mathrm{a}$ & $9.4 \mathrm{~b}$ & $8.8 \mathrm{c}$ & $1.4 \mathrm{a}$ & $1.3 \mathrm{~b}$ & $1.2 \mathrm{~b}$ & $4.6 \mathrm{a}$ & $4.3 \mathrm{a}$ & $3.9 \mathrm{~b}$ & $7.5 \mathrm{a}$ & $7.7 \mathrm{a}$ & $7.5 \mathrm{a}$ \\
\hline 1 Oct. & $26 \mathrm{a}$ & $27 \mathrm{a}$ & $27 \mathrm{a}$ & $10.5 \mathrm{a}$ & $9.7 \mathrm{~b}$ & $8.9 \mathrm{c}$ & $1.3 \mathrm{a}$ & $1.2 \mathrm{~b}$ & $1.1 \mathrm{~b}$ & $5.3 \mathrm{a}$ & $4.9 \mathrm{~b}$ & $4.5 \mathrm{c}$ & $8.4 \mathrm{a}$ & $8.3 \mathrm{a}$ & $8.2 \mathrm{a}$ \\
\hline 8 Oct. & $27 \mathrm{a}$ & $27 \mathrm{a}$ & $28 \mathrm{a}$ & $11.1 \mathrm{a}$ & $10.0 \mathrm{~b}$ & $9.2 \mathrm{c}$ & $1.3 \mathrm{a}$ & $1.2 \mathrm{~b}$ & $1.1 \mathrm{c}$ & $5.9 \mathrm{a}$ & $5.2 \mathrm{~b}$ & $4.8 \mathrm{c}$ & $8.7 \mathrm{a}$ & $8.6 \mathrm{a}$ & $8.5 \mathrm{a}$ \\
\hline 15 Oct. & $26 \mathrm{a}$ & $26 \mathrm{a}$ & $28 \mathrm{a}$ & $11.9 \mathrm{a}$ & $10.2 \mathrm{~b}$ & $9.5 \mathrm{c}$ & $1.4 \mathrm{a}$ & $1.1 \mathrm{~b}$ & $1.1 \mathrm{~b}$ & $6.5 \mathrm{a}$ & $5.9 \mathrm{a}$ & $5.2 \mathrm{~b}$ & $8.9 \mathrm{a}$ & $9.7 \mathrm{a}$ & $9.0 \mathrm{a}$ \\
\hline \multicolumn{16}{|l|}{2008} \\
\hline 30 Sept. & $29 \mathrm{~b}$ & $26 a$ & $28 \mathrm{~b}$ & $8.5 \mathrm{~b}$ & $9.4 \mathrm{a}$ & $8.5 \mathrm{~b}$ & $1.1 \mathrm{a}$ & $1.1 \mathrm{a}$ & $1.1 \mathrm{a}$ & $4.1 \mathrm{~b}$ & $4.9 \mathrm{a}$ & $4.2 \mathrm{~b}$ & $8.0 \mathrm{a}$ & $8.5 \mathrm{a}$ & $8.2 \mathrm{a}$ \\
\hline 7 Oct. & $29 \mathrm{a}$ & $28 \mathrm{a}$ & $28 \mathrm{a}$ & $8.7 \mathrm{~b}$ & $9.6 \mathrm{a}$ & $8.5 \mathrm{~b}$ & $1.0 \mathrm{~b}$ & $1.1 \mathrm{a}$ & $1.0 \mathrm{~b}$ & $4.6 \mathrm{~b}$ & $5.3 \mathrm{a}$ & $4.4 \mathrm{~b}$ & $8.7 \mathrm{a}$ & $9.1 \mathrm{a}$ & $8.5 \mathrm{a}$ \\
\hline 14 Oct. & $29 \mathrm{a}$ & $28 \mathrm{a}$ & $28 \mathrm{a}$ & $8.7 \mathrm{~b}$ & $9.6 \mathrm{a}$ & $8.6 \mathrm{~b}$ & $1.0 \mathrm{a}$ & $1.1 \mathrm{a}$ & $1.0 \mathrm{a}$ & $4.6 \mathrm{~b}$ & $5.3 \mathrm{a}$ & $4.6 \mathrm{~b}$ & $8.7 \mathrm{a}$ & $9.0 \mathrm{a}$ & $8.7 \mathrm{a}$ \\
\hline 21 Oct. & $29 \mathrm{a}$ & $29 \mathrm{a}$ & $28 \mathrm{a}$ & $9.0 \mathrm{~b}$ & $10.0 \mathrm{a}$ & $9.0 \mathrm{~b}$ & $1.0 \mathrm{~b}$ & $1.1 \mathrm{a}$ & $0.9 \mathrm{~b}$ & $5.1 \mathrm{~b}$ & $5.7 \mathrm{a}$ & $5.2 \mathrm{~b}$ & $9.5 \mathrm{a}$ & $9.6 \mathrm{a}$ & $9.6 \mathrm{a}$ \\
\hline 28 Oct. & $29 \mathrm{a}$ & $29 \mathrm{a}$ & $28 \mathrm{a}$ & $9.3 \mathrm{~b}$ & $10.5 \mathrm{a}$ & $9.1 \mathrm{~b}$ & $0.9 \mathrm{~b}$ & $1.0 \mathrm{a}$ & $0.9 \mathrm{~b}$ & $5.6 \mathrm{~b}$ & $6.5 \mathrm{a}$ & $5.5 \mathrm{~b}$ & $10.2 \mathrm{a}$ & $10.7 \mathrm{a}$ & $10.2 \mathrm{a}$ \\
\hline
\end{tabular}

${ }^{\mathrm{z}}$ Fruit harvested, 30 Oct. 2006, 15 Oct. 2007, and 29 Oct. 2008.

${ }^{\mathrm{y}} \mathrm{T} 1, \mathrm{~T} 2$, and $\mathrm{T} 3$ refer to the three irrigation treatments conducted over the 4 years of the experiment.

${ }^{x}$ Values in a row across treatments on a given date for a given fruit characteristic that are followed by different letters are significantly different by Fisher's protected least significant difference test at $P \leq 0.05$.

Table 4. Effect of irrigation treatment on color lightness $\left(\mathrm{L}^{*}\right)$, chroma, and hue as measured by a colorimeter ${ }^{2}$ and color as perceived by a human observer compared with a color chart ${ }^{y}$ from 'Beck-Earli' navel orange fruit grown under three irrigation regimes in the San Joaquin Valley of California in 2006, 2007, and 2008. ${ }^{\mathrm{x}}$

\begin{tabular}{|c|c|c|c|c|c|c|c|c|c|c|c|c|}
\hline \multirow[b]{2}{*}{ Sample date } & \multicolumn{3}{|c|}{$\mathrm{L}^{*}$} & \multicolumn{3}{|c|}{ Chroma } & \multicolumn{3}{|c|}{ Hue } & \multicolumn{3}{|c|}{ Color chart } \\
\hline & $\mathrm{T} 1^{3}$ & T2 & T3 & T1 & T2 & T3 & T1 & $\mathrm{T} 2$ & T3 & T1 & $\mathrm{T} 2$ & T3 \\
\hline 26 Sept. & $49.9 \mathrm{a}^{\mathrm{w}}$ & $49.9 \mathrm{a}$ & $49.2 \mathrm{a}$ & $38.3 \mathrm{a}$ & $37.8 \mathrm{a}$ & $37.5 \mathrm{a}$ & $120.2 \mathrm{a}$ & $120.4 \mathrm{a}$ & $120.2 \mathrm{a}$ & $4.0 \mathrm{a}$ & $4.0 \mathrm{a}$ & $4.0 \mathrm{a}$ \\
\hline 17 Oct. & $58.5 \mathrm{a}$ & $58.3 \mathrm{a}$ & $56.1 \mathrm{~b}$ & $46.6 \mathrm{a}$ & $46.5 \mathrm{a}$ & $44.4 \mathrm{a}$ & $113.3 \mathrm{~b}$ & $113.5 \mathrm{~b}$ & $115.6 \mathrm{a}$ & $4.0 \mathrm{a}$ & $4.0 \mathrm{a}$ & $4.0 \mathrm{a}$ \\
\hline 24 Oct. & $64.5 \mathrm{a}$ & $63.0 \mathrm{a}$ & $60.8 \mathrm{~b}$ & $55.0 \mathrm{a}$ & $52.9 \mathrm{ab}$ & $50.9 \mathrm{~b}$ & $104.8 \mathrm{~b}$ & $107.7 \mathrm{a}$ & $109.0 \mathrm{a}$ & $5.5 \mathrm{a}$ & $5.4 \mathrm{a}$ & $5.2 \mathrm{a}$ \\
\hline 30 Oct. & $65.7 \mathrm{a}$ & $64.0 \mathrm{a}$ & $59.9 \mathrm{~b}$ & $57.5 \mathrm{a}$ & $56.1 \mathrm{a}$ & $51.2 \mathrm{~b}$ & $98.5 \mathrm{~b}$ & $101.0 \mathrm{~b}$ & $106.0 \mathrm{a}$ & $6.0 \mathrm{a}$ & $5.8 \mathrm{a}$ & $5.2 \mathrm{~b}$ \\
\hline 25 Sept. & $57.4 \mathrm{a}$ & $55.1 \mathrm{~b}$ & $53.7 \mathrm{~b}$ & $45.2 \mathrm{a}$ & $42.4 \mathrm{~b}$ & $41.0 \mathrm{~b}$ & $117.6 \mathrm{~b}$ & $119.8 \mathrm{a}$ & $120.2 \mathrm{a}$ & $4.8 \mathrm{a}$ & $4.3 \mathrm{ab}$ & $4.1 \mathrm{~b}$ \\
\hline 1 Oct. & $58.0 \mathrm{a}$ & $56.4 \mathrm{a}$ & $55.2 \mathrm{~b}$ & $45.5 \mathrm{a}$ & $43.2 \mathrm{~b}$ & $42.2 \mathrm{~b}$ & $116.2 \mathrm{~b}$ & $118.0 \mathrm{a}$ & $119.0 \mathrm{a}$ & $4.9 \mathrm{a}$ & $4.6 \mathrm{~b}$ & $4.3 \mathrm{c}$ \\
\hline 8 Oct. & $62.0 \mathrm{a}$ & $60.9 \mathrm{a}$ & $59.5 \mathrm{~b}$ & $50.5 \mathrm{a}$ & $48.2 \mathrm{~b}$ & $46.6 \mathrm{c}$ & $111.0 \mathrm{~b}$ & $113.8 \mathrm{a}$ & $114.9 \mathrm{a}$ & $5.3 \mathrm{a}$ & $5.2 \mathrm{a}$ & $5.0 \mathrm{a}$ \\
\hline 15 Oct. & $67.8 \mathrm{a}$ & $64.2 \mathrm{~b}$ & $63.3 \mathrm{~b}$ & $59.8 \mathrm{a}$ & $54.2 \mathrm{~b}$ & $53.2 \mathrm{~b}$ & $102.7 \mathrm{~b}$ & $109.1 \mathrm{a}$ & $110.4 \mathrm{a}$ & $6.0 \mathrm{a}$ & $5.2 \mathrm{~b}$ & $5.2 \mathrm{~b}$ \\
\hline \multicolumn{13}{|l|}{2008} \\
\hline 30 Sept. & $52.0 \mathrm{~b}$ & $53.3 \mathrm{a}$ & $53.6 \mathrm{a}$ & $39.3 \mathrm{a}$ & $41.1 \mathrm{a}$ & $40.7 \mathrm{a}$ & $123.1 \mathrm{a}$ & $122.0 \mathrm{~b}$ & $122.1 \mathrm{~b}$ & $4.0 \mathrm{a}$ & $4.0 \mathrm{a}$ & $4.0 \mathrm{a}$ \\
\hline
\end{tabular}

${ }^{\mathrm{z}}$ Measured with a Minolta C300 colorimeter.

${ }^{y}$ Fruit color based on comparison of fruit to color chart with values representing colors from 1 to 13 , with 1 being greenest and 13 reddish orange.

${ }^{x} \mathrm{~T} 1, \mathrm{~T} 2$, and T3 refer to the three irrigation treatments conducted over the 3 years of the experiment. Fruit harvested, Oct. 30 in 2006, Oct.15 in 2007, and Oct. 29 in 2008 .

"Values for each characteristic compared across the three treatments within a row for a given date that are followed by different letters are significantly different by Fisher's protected least significant difference test at $P \leq 0.5$.

Table 5. Effect of the side of the tree (south or north) averaged across irrigation treatments on percent juice, soluble solids concentration, titratable acid, BrimA index, and color of 'Beck-Earli' navel fruit in the southern San Joaquin Valley.

\begin{tabular}{|c|c|c|c|c|c|c|c|c|c|c|c|c|}
\hline \multirow[b]{2}{*}{ Sample date } & \multicolumn{2}{|c|}{ Juice wt/fruit wt (\%) } & \multicolumn{2}{|c|}{ Soluble solids content (SSC) (\%) } & \multicolumn{2}{|c|}{ Titratable acid (TA) (\%) } & \multicolumn{2}{|c|}{ BrimA } & \multicolumn{2}{|c|}{ SSC:TA Ratio } & \multicolumn{2}{|c|}{ Color chart $^{\mathrm{y}}$} \\
\hline & South & North & South & North & South & North & South & North & South & North & South & North \\
\hline 1 Oct. & $26 \mathrm{~b}$ & $27 \mathrm{a}$ & $10.2 \mathrm{a}$ & $9.3 \mathrm{~b}$ & $1.0 \mathrm{~b}$ & $1.4 \mathrm{a}$ & $6.0 \mathrm{a}$ & $3.8 \mathrm{~b}$ & $9.8 \mathrm{a}$ & $6.8 \mathrm{~b}$ & $4.6 \mathrm{a}$ & $4.7 \mathrm{a}$ \\
\hline 8 Oct. & $26 \mathrm{~b}$ & $28 \mathrm{a}$ & $10.6 \mathrm{a}$ & $9.7 \mathrm{~b}$ & $1.1 \mathrm{~b}$ & $1.3 \mathrm{a}$ & $6.3 \mathrm{a}$ & $4.3 \mathrm{~b}$ & $10.0 \mathrm{a}$ & $7.2 \mathrm{~b}$ & $5.3 \mathrm{a}$ & 5.1 \\
\hline
\end{tabular}

${ }^{\mathrm{z}}$ Fruit harvested 15 Oct. 2007.

${ }^{y}$ Color based on color chips with values representing colors from 1 to 13 , with 1 being greenest and 13 a reddish orange on the U.C. color chart system.

${ }^{x}$ Each table value is averaged across treatments ( 10 oranges per replicate $\times$ five replicates $\times$ three treatments).

walues from the north or south sides of the tree for a given fruit characteristic on a given date that are followed by different letters are significantly different by

Fisher's protected least significant difference test at $P \leq 0.05$. 
Table 6. Effect of irrigation treatment on yield, fruit size, and grade of 'Beck-Earli' navel orange fruit at harvest in the southern San Joaquin Valley in 2006, 2007, and 2008 .

\begin{tabular}{|c|c|c|c|c|c|c|c|c|c|c|c|c|c|}
\hline \multirow{2}{*}{$\frac{\mathrm{Yr}}{2006}$} & \multirow{2}{*}{$\begin{array}{l}\text { Irrigation } \\
\text { treatment }\end{array}$} & \multirow{2}{*}{$\begin{array}{c}\text { Yield } \\
(\mathrm{kg} / \text { tree })\end{array}$} & \multirow{2}{*}{$\begin{array}{c}\text { Fruit/tree } \\
\text { number }\end{array}$} & \multicolumn{7}{|c|}{ Percent of fruit per tree in various size categories } & \multicolumn{3}{|c|}{ Fruit grade, percent in category } \\
\hline & & & & Less than $48^{z}$ & 48 & 56 & 72 & 88 & 113 & Greater than 113 & Fancy & Choice & Juice \\
\hline & T2 & $73 \mathrm{a}$ & $267 \mathrm{a}$ & $15.5 \mathrm{~b}$ & $25.4 \mathrm{a}$ & $17.9 \mathrm{a}$ & $24.4 \mathrm{a}$ & $10.6 \mathrm{a}$ & $3.7 \mathrm{a}$ & $2.4 \mathrm{a}$ & $96.5 \mathrm{a}$ & $3.0 \mathrm{a}$ & $0.5 \mathrm{a}$ \\
\hline 2007 & $\mathrm{~T} 1$ & $118 \mathrm{c}$ & $566 \mathrm{~b}$ & $4.5^{3} \mathrm{c}$ & $9.0 \mathrm{c}$ & $22.9 \mathrm{~b}$ & $31.0 \mathrm{a}$ & $25.9 \mathrm{a}$ & $6.0 \mathrm{a}$ & $0.7 \mathrm{a}$ & $53.4 \mathrm{c}$ & $41.6 \mathrm{a}$ & $5.0 \mathrm{a}$ \\
\hline & $\mathrm{T} 2$ & $135 \mathrm{~b}$ & $584 \mathrm{~b}$ & $10.3 \mathrm{~b}$ & $18.0 \mathrm{~b}$ & $30.2 \mathrm{a}$ & $25.3 \mathrm{~b}$ & $13.9 \mathrm{~b}$ & $1.8 \mathrm{~b}$ & $0.1 \mathrm{~b}$ & $61.9 \mathrm{~b}$ & $33.9 \mathrm{~b}$ & $4.2 \mathrm{ab}$ \\
\hline & $\mathrm{T} 3$ & 162 a & $646 \mathrm{a}$ & $16.3 \mathrm{a}$ & $20.0 \mathrm{a}$ & $31.2 \mathrm{a}$ & $21.9 \mathrm{~b}$ & $9.5 \mathrm{ac}$ & $1.0 \mathrm{~b}$ & $0.1 \mathrm{~b}$ & $67.9 \mathrm{a}$ & $28.8 \mathrm{c}$ & $3.3 \mathrm{~b}$ \\
\hline & $\mathrm{T} 2$ & $99 \mathrm{a}$ & $382 \mathrm{a}$ & $17.7 \mathrm{a}$ & $17.4 \mathrm{a}$ & $36.1 \mathrm{a}$ & $15.6 \mathrm{a}$ & $7.5 \mathrm{a}$ & $3.6 \mathrm{a}$ & $2.1 \mathrm{a}$ & $51.7 \mathrm{~b}$ & $32.9 \mathrm{a}$ & $15.3 \mathrm{a}$ \\
\hline & $\mathrm{T} 3$ & $114 \mathrm{a}$ & $404 \mathrm{a}$ & $26.5 \mathrm{a}$ & $19.2 \mathrm{a}$ & $31.9 \mathrm{a}$ & $13.1 \mathrm{a}$ & $5.5 \mathrm{a}$ & $2.4 \mathrm{a}$ & $1.4 \mathrm{a}$ & $55.6 \mathrm{ab}$ & $32.1 \mathrm{a}$ & $12.2 \mathrm{~b}$ \\
\hline
\end{tabular}

${ }^{\mathrm{z}}$ Numbers of fruit required to fill a 17-kg standard commercial California carton. Count size categories 48, 56, 72, 88, and 113 correspond to average transverse fruit diameters of $88,84,77,72$, and $66 \mathrm{~mm}$, respectively.

${ }^{\mathrm{y}} \mathrm{T} 1, \mathrm{~T} 2$, and $\mathrm{T} 3$ refer to the three irrigation treatments conducted over the 3 years of the experiment.

${ }^{\mathrm{x}}$ Values in the same column for a given year followed by different letters are significantly different by Fisher's protected least significant test at $P \leq 0.05$.

Table 7. Effect of irrigation treatment on 'Beck Earli' navel orange fruit color at harvest as evaluated by the automated color sensor in the experimental packline at the U.C. Lindcove Research and Extension, 2006, 2007, and 2008.

\begin{tabular}{|c|c|c|c|c|}
\hline \multirow[b]{2}{*}{$\mathrm{Yr}$} & \multirow{2}{*}{$\begin{array}{l}\text { Irrigation } \\
\text { treatment }\end{array}$} & \multicolumn{3}{|c|}{ Percent of fruit per tree in three color categories } \\
\hline & & Green & Yellow-green & Orange \\
\hline \multirow[t]{3}{*}{$\overline{2006}$} & $\mathrm{~T} 1^{\mathrm{z}}$ & $83.8^{y} b^{x}$ & $11.9 \mathrm{a}$ & $4.3 \mathrm{a}$ \\
\hline & $\mathrm{T} 2$ & $90.2 \mathrm{ab}$ & $7.6 \mathrm{ab}$ & $2.2 \mathrm{~b}$ \\
\hline & $\mathrm{T} 3$ & $95.4 \mathrm{a}$ & $3.8 \mathrm{~b}$ & $0.7 \mathrm{~b}$ \\
\hline \multirow[t]{3}{*}{2007} & $\mathrm{~T} 1$ & $58.0 \mathrm{c}$ & $42.0 \mathrm{a}$ & $0.0 \mathrm{a}$ \\
\hline & $\mathrm{T} 2$ & $78.8 \mathrm{~b}$ & $21.2 \mathrm{~b}$ & $0.0 \mathrm{a}$ \\
\hline & $\mathrm{T} 3$ & $92.2 \mathrm{a}$ & $7.8 \mathrm{c}$ & $0.0 \mathrm{a}$ \\
\hline \multirow[t]{3}{*}{2008} & $\mathrm{~T} 1$ & $0.0 \mathrm{a}$ & $100.0 \mathrm{a}$ & $0.0 \mathrm{a}$ \\
\hline & $\mathrm{T} 2$ & $0.0 \mathrm{a}$ & $100.0 \mathrm{a}$ & $0.0 \mathrm{a}$ \\
\hline & $\mathrm{T} 3$ & $0.0 \mathrm{a}$ & $100.0 \mathrm{a}$ & $0.0 \mathrm{a}$ \\
\hline
\end{tabular}

${ }^{\mathrm{z}}$ Each value is the average percentage of fruit in each color category. Each value is calculated from measurement made individually on all fruits harvested from three trees in each of five replicates of each treatment.

${ }^{\mathrm{y}} \mathrm{T} 1, \mathrm{~T} 2$, and $\mathrm{T} 3$ refer to the three irrigation treatments conducted over the 3 years of the experiment. Fruit harvested, 30 Oct. in 2006, 15 Oct. in 2007, and 29 Oct. in 2008.

${ }^{x}$ Values in the same column for a given year followed by different letters are significantly different by Fisher's protected least significant difference test at $P \leq 0.05$.

Water stress and differences in yield and fruit quality at harvest. Only in 2007 were yield by weight and total number of fruit per tree negatively affected by water stress (Table 6). In 2007, fruit weight per tree in $\mathrm{T} 1$ and T2 were $72 \%$ and $83 \%$, respectively, of that of the fully irrigated trees (Table 6). Whether this result was attributable to carryover effects of water stress from 2006 through 2007 or simply to the increased severity of the given stress in 2007 is not separable in our experimental design. The decrease in fruit weight per tree in T1 was largely the result of a decrease in individual fruit size because fruit numbers between $\mathrm{T} 1$ and $\mathrm{T} 2$ were not different and fruit from water-stressed trees shifted toward smaller sizes in 2007. The most common fruit size was 72 fruit per standard $17-\mathrm{kg}$ commercial California carton (75 to $80 \mathrm{~mm}$ in transverse diameter) in T1 and Size 56 (81 to $88 \mathrm{~mm}$ in diameter) in T2 and T3 (Table 6). Differences in fruit size are important economically. Most years, early in the harvest season, a commercial $17-\mathrm{kg}$ carton of largesized fruit is worth more than a carton of smaller-sized fruit (Kallsen, 2001).

Juice percentage was unaffected by water stress in our study. This contrasts with the results of late-season water stresses reported by Perez-Perez et al. (2009) of decreased juice percentage in 'Lane Late' navel orange or of Romero et al. (2006) in which severe water stress in 'Clemenules' mandarin increased juice percentage.

At harvest, T1 in 2006 and 2007, and T2 in 2007 demonstrated earlier color development, as measured by automated color sensor in the packline, than T3 (Table 7). The result of Romero et al. (2006), who found that the most severe water stress decreased peel color in 'Clemenules' mandarin, is not directly comparable to ours because they measured peel color in late November at which time peel color had largely completed the transition to orange. Fruit grade suffered as a result of the late-season irrigation stress in 2007. In T1, only $53.4 \%$ of the fruit was packable as fancy [i.e. first grade (U.S. Dept. Agr., 2011)] compared with $67.9 \%$ in T3. Even the relatively mild stress of T2 in 2008 (Fig. 3) resulted in a reduction of $7.3 \%$ in the amount of total fruit that was packable as fancy in T2 compared with T3 (Table 6). The loss of grade in T1 and T2 in 2007 appeared to be associated with the development of a less desirable sheepnosed or stem-end tapered fruit (Syvertsen et al., 2005). Treatment 1, the most heavily stressed treatment of the experiment in 2006 and 2007, produced yield, fruit numbers, fruit grade, and fruit quality comparable to $\mathrm{T} 3$ when irrigated similarly to $\mathrm{T} 3 \mathrm{in}$ 2008 (Tables 3, 6, and 7).

Sensory perception. Sensory panelists were not able to differentiate between fruit from T1 and T3 in 2007 or from T2 and T3 in 2008. Table 3 shows that for both the 2007 and 2008 tests, juice BrimA was significantly different between treatments. However, because the panelists were presented individual fruit, the fruit-to-fruit variability may have masked the difference detected in BrimA index and SSC. Irrigation treatment had no effect on juice SSC:TA ratios (Table 3).

Our research suggests that late-season water stress may produce a fruit with less green and more orange color earlier in the season when even a few days difference in harvest timing can mean a large price differential in fruit value. However, the more severe water stress levels achieved in 2007 negatively impacted fruit yield, size, and grade, which would reduce grower profitability. Our results suggest that late-season water stresses would have to be relatively mild and applied with care to achieve earlier color development without reducing other desirable fruit quality characteristics. Furthermore, the increased levels of SSC and BrimA index that were achievable with late-season water stress did not improve consumer sensory perception of the fruit and would thus be unlikely to increase sales demand for navels early in the harvest season.

\section{Conclusions}

Three years of late-season irrigation stresses initiated in August in the southern San Joaquin Valley of California resulted in decreasing midday SLWP ranging from -1.4 $\mathrm{MPa}$ in early September to a maximum of $-2.5 \mathrm{MPa}$ at harvest in an early-maturing 'Beck-Earli' navel orange variety. Compared with fully irrigated navel orange trees, increasing degrees of late-season water stress increased juice SSC and TA, hastened development of orange color, and, when severe, 
decreased fruit yield by weight, fruit numbers, fruit size, and grade. The SSC:TA ratios, and the juiciness of the fruit, either expressed as a ratio of juice weight or volume to fruit weight, were unaffected by late-season irrigation stress. Consumers were not able to differentiate between the taste and other sensory parameters of fruit from trees that were fully irrigated versus water-stressed at harvests in mid- to late October despite measured differences in SSC, TA, BrimA index, and color.

Our results indicate that growers that have insufficient water midsummer to fully irrigate an orchard could reduce irrigation significantly to the levels of tree stress reported in this study, but this would impact yield, size, or grade. Results also suggest that yield and fruit quality characteristics of trees that were subjected to 2 consecutive years of lateseason irrigation stress returned the next year to that of unstressed trees once full annual irrigation was restored.

Incremental gains in knowledge such as that developed in this study provide orange growers a more complete understanding of the tradeoffs that occur among fruit quality and yield factors with late-season irrigation practices. This knowledge should improve the ability of growers to allocate water resources more effectively, improve profitability, and provide the consumer with a more acceptable early-maturing navel orange.

\section{Literature Cited}

Barry, G.H., W.S. Castle, and F.S. Davies. 2004. Rootstocks and plant water relations affect sugar accumulation of 'Valencia' sweet orange via osmotic adjustment. J. Amer. Soc. Hort. Sci. 129:881-889.

California Dept. of Water Resources. 1993. Crop water use-A guide to scheduling irrigations in the southern San Joaquin Valley, 1977-1991. Sacramento, CA. Mar.

CIMIS. California Dept. of Water Resources, Div. of Statewide Integrated Water Mgt., Water Use and Efficiency Branch, California irrigation mgt. info. system. 27 Apr. 2011. <http://www.cimis. water.ca.gov/cimis/infoEtoCimisEquation.jsp>.

Elfving, D.C., M.R. Kaufman, and A.E. Hall. 1972. Interpreting leaf water potential measurements with a model of the soil-plant-atmosphere continuum. Physiol. Plant. 27:161-168.

Goldhamer, D.A. 2007. Regulated deficit irrigation in trees and vines, p. 70-80. In: Holliday, L. (ed.). Agr. Water Mgt.: Proc. of a workshop in Tunisia (Series: Strengthening science-based decision making in developing countries). The Natl. Academies Press, Washington, DC.

Goldhamer, D.A. and M. Salinas. 2000. Evaluation of regulated deficit irrigation on mature orange trees grown under high evaporative demand. Proc. Intl. Soc. Citricult. IX Congr. p. 227-231. Goldhamer, D.A., M. Salinas, M.S. Anaya, and A.M. Elvira. 2001. Peach trees perform similarly despite different irrigation scheduling methods. Calif. Agr. 55:25-29.

Hilgeman, R.H. and F.O. Sharp. 1970. Response of 'Valencia' orange trees to four soil water schedules during 20 years. J. Amer. Soc. Hort. Sci. 95:739-745.

Hutton, R.J., J.J. Landsberg, and B.G. Sutton. 2007. Timing irrigation to suit phenology: A means of reducing water use without compromising fruit yield and quality. Aust. J. Exp. Agr. 47:71-80.

Jordan, R., R. Seelye, and A. McGlone. 2001. A sensory-based alternative to Brix/acid ratio. Food Technol. 55:36-44.

Kallsen, C.E. 2001. Petroleum oils as navel orange fruit thinning agents. HortTechnology 11:189193.

Miller, E.V. and J. Turnbull. 1948. Relation of irrigation to creasing in oranges in Florida. The Citrus Ind. 29:16-17.

Minolta Co. Ltd. 1994. Precise color communication. Toyotsu-Cho, Suita-shi, Osaka, Japan.

McGuire, R.G. 1992. Reporting of objective color measurements. HortScience 27:1254-1255.

Naqvi, S.A.M.H. 2004. Diagnosis and management of certain important fungal diseases of citrus, p. 339-360. In: Naqvi, S.A.M.H. (ed.). Diseases of fruits and vegetables: Diagnosis and management. Vol. 1. Kluwer Academic Publishers, Dordrecht, The Netherlands.

Obenland, D., S. Collin, B. Mackey, J. Sievert, K. Fjeld, and M.L. Arpaia. 2009. Determinants of flavor acceptability during the maturation of navel oranges. Postharvest Biol. Technol. 52: 156-163.

Oosterhuis, D.M., M.L. Parker, S.D. Wullschleger, and K.S. Kim. 1988. The citrus leaf cuticle in relation to measurement of leaf water potential using thermocouple psychrometers. Plant Cell Environ. 11:129-135.

Perez-Perez, J.G., J.M. Robles, and P. Botia. 2009. Influence of deficit irrigation in phase III of fruit growth on fruit quality in 'lane late' sweet orange. Agr. Water Mgt. 96:969-974.

Pruitt, W.O. and J. Doorenbos. 1977. Empirical calibration a requisite for evapotranspiration formulae based on daily or longer mean climatic data. Proc. of the Intl. Round Table Conf. on 'evapotranspiration,' Budapest, Hungary.

Pruitt, W.O., E. Fereres, K. Kaita, and R.L. Snyder. 1987. Reference evapotranspiration (ETo) for California. Agr. Expt. Station. Univ. of California. Div. of ANR. Bul.1922.

Romero, P., J.M. Navarro, J. Perez-Perez, F. GarciaSanchez, A. Gomez-Gomez, V. Martinez, and P. Botia. 2006. Deficit irrigation and rootstock: Their effects on water relations, vegetative development, yield, fruit quality and mineral nutrition of Clemenules mandarin. Tree Physiol. 26:1537-1548.

Schreider, L. and M. Riedereer. 1996. Ecophysiology of cuticular transpiration: Comparative investigation of cuticular water permeability of plant species from different habitats. Oecologia 107:426-432.

Shackel, K.A. 2011. A plant-based approach to deficit irrigation in trees and vines. HortScience 46:173-177.

Shackel, K.A., H. Ahmadi, W. Biasi, R. Buchner, D. Goldhamer, S. Gurusinghe, J. Hasey, D. Kester, B. Krueger, B. Lampinen, G. McGourty, W. Micke, E. Mitcham, B. Olson, K. Pelletrau, H. Philips, D. Ramos, L. Schwankl, S. Sibbett, R. Snyder, S. Southwick, M. Stevenson, M. Thorpe, S. Weinbaum, and J. Yeager. 1997. Plant water status as an index of irrigation need. HortTechnology 7:23-29.

Shorner, I. and Y. Erner. 1989. The nature of oleocellosis in citrus fruits. Bot. Gaz. 150: 281-288.

State of California. 2003. California Code of Regulations, Title 3, Division 3, Chapter 1. Subchapter 4, Article 22, Section 1430.36. California Dep. of Food and Agr. 27 Apr. 2011. <http://www.cdfa.ca.gov/is/regulations. html>.

Syvertsen, J.P. and L.G. Albrigo. 1980. Some effects of grapefruit tree canopy position on microclimate, water relations, fruit yield, and juice quality. J. Amer. Soc. Hort. Sci. 105:454 459.

Syvertsen, J.P., L.G. Albrigo, J.M. Dunlop, M.A Ritenour, and R.C. Vachon. 2005. Growth conditions, crop load, and fruit size affect sheepnosing in grapefruit. Proc. Florida State Hort. Soc. 118:28-35.

Ting, S.V. and R.L. Rouseff. 1986. Citrus fruits and their products, analysis and technology. Marcel Dekker, New York, NY. p. 35-47.

Treeby, M.T., R.E. Henriod, K.B. Bevington, D.J. Milne, and R. Storey. 2007. Irrigation management and rootstock effects on navel orange [Citrus sinensis (L.) Osbeck] fruit quality. Agr. Water Mgt. 91:24-32.

U.S. Dept. Agr. 2009a. Natl. Agr. Stat. Serv. Citrus fruits 2009 summary. 27 Apr. 2011. <http:// www.nass.usda.gov/>.

U.S. Dept. Agr. 2009b. Natl. Resource Conservation Serv. Soil survey of Kern County, California, southwest part. 27 Apr. 2011. <http://www2. ftw.nrcs.usda.gov/osd/dat/C/CERINI.html>.

U.S. Dept. Agr. 2010. Natl. Agr. Stat. Serv. Citrus fruits 2010 summary. 27 Apr. 2011. <http:// www.nass.usda.gov/>.

U.S. Dept. Agr. 2011. Agr. Marketing Serv. Grading certification and verification. $27 \mathrm{Apr}$. 2011. <http://www.ams.usda.gov/AMSv1.0/ standards $>$.

Voss, D.H. 1992. Relating colorimeter measurements of plant color to the Royal Horticultural Society Colour Chart. HortScience 27:12561260.

Yakushiji, H., H. Nonami, T. Fukuyama, S. Ono, N. Takagi, and Y. Hashimoto. 1996. Sugar accumulation enhanced by osmoregulation in satsuma mandarin fruit. J. Amer. Soc. Hort. Sci. 121:466-472. 